\title{
Impact of managed aquifer recharge structure on river flow regimes in arid and semi-arid climates
}

\author{
Navid Yaraghia,*, Anna-kaisa Ronkanen $^{\mathrm{a}}$, Hamid Darabi ${ }^{\mathrm{b}}$, Bjørn Kløve ${ }^{\mathrm{a}}$, Ali Torabi Haghighi ${ }^{\mathrm{a}}$ \\ ${ }^{a}$ Water, energy and environmental engineering research unit, University of Oulu, Oulu, Finland. \\ ${ }^{b}$ Watershed management department, Sari Agriculture Science and Natural Resources University, Iran.
}

\begin{abstract}
:
Managed aquifer recharge (MAR) structure is widely used to expand groundwater resources. In arid regions with flash flooding, MAR can also be used as a flood control structure to decrease peak discharge of rivers. In this paper, we present a method for quantifying the role of MAR in head water systems and assess its impact on the total water balance in a river basin. The method is based on rainfall-runoff modeling, reservoir flood routing, recharge analysis and river flow analysis. For the case selected, Kamal Abad MAR in Lake Maharlou basin in southern Iran, we analyzed changes in the downstream river regime using two scenarios (with MAR and without MAR) with different return periods. The results revealed a significant impact of MAR on river flow in terms of changes in flow timing, magnitude and variability. With MAR, the ephemeral river studied became disconnected from the main stream, albeit, whereas the case without MAR, floods with return period higher than 10 years would be connected to the downstream. Even though, MAR structures are useful in arid and semi-arid climates for irrigation water supply, their placing and designing need more attention. The developed method can be used to assess the impacts of MAR on river flow and find the best location for it to make the connection of the ephemeral river and downstream river, an issue which has not received much attention in hydrological research.
\end{abstract}

Keywords: Groundwater, Flood, Water retention, Dam, Irrigation

\section{Introduction}

In arid and semi-arid regions, groundwater $(\mathrm{GW})$ provides a stable water resource and supply to meet agricultural demands (Prathapar et al., 2015). However, excessive GW exploitation due to expansion of agriculture has led to significant depletion of GW resources (Feike et al., 2017; Jyrkama and Sykes, 2007; Zaidi et al., 2015). This has effects on socioeconomic sectors and ecosystems onwards (UNWater, 2016). Various artificial GW recharge techniques based on direct and indirect infiltration and percolation of surface water have been developed. One such method is Managed Aquifer Recharge (MAR) structure, which has been used to extend GW availability and restore GW levels after depletion (Ronayne et al., 2017). Especially in arid regions, MAR is an important method to maintain, enhance and secure stressed groundwater systems (Dillon, 2005; Dillon et al., 2019).

In Iran, a common MAR approach is to construct a dam above an aquifer to store water during flood events (Nafarzadegan et al., 2012). The set-up includes an earth embankment (a uniform earth dam), a free spillway to avoid flow over topping the embankment during extreme runoff conditions (e.g. high return period runoff) and an outlet pipe at the bottom of the structure (Ajmal et al., 2015; Sakakibara et al., 2017; Yiediboe et al., 2015). The benefit of the method depends on the amount of river water recharged to the aquifer and the reduction in peak flow achieved. Increased dams and artificial recharge can alter the downstream river regime (Ashraf et al., 2016; Askar, 2013; Torabi Haghighi and Kløve, 2015, 2013).

The main goal of this study is to develop a multi-stage framework for quantifying the impact of MAR on downstream river flow and to apply it in the case of the Kamal Abad MAR in Lake Maharlou 
basin, southern Iran. In the method, flow regime change due to MAR are assessed along the river. Based on this the location of MAR structures can be optimized to lower the environmental impact and sustain sufficient flow in the river channel. Each step of this multi-stage framework exists already and is well documented (Askar, 2013; Beven, 2012; Choudhary and Chahar, 2007; Ghahreman and Abkhezr, 2004; Ghayoumian et al., 2007; Jahanshahi and Zare, 2016; Mancosu et al., 2015; Wösten et al., 2013). However, in our novel approach these steps are combined in order to assess the impact of small structures, particularly MAR, on river flow regime and the efficiency of the structures. The aims of this study was to combine previously used procedures and focus on the stage of the river after MAR structure. Based on this we studied the impacts of MAR on the length of the river before it gets disappeared as it is common situation in arid climatic region.

\section{Material and Methods}

\subsection{Study area}

Fars province in southern Iran $\left(27^{\circ} 30^{\prime}-31^{\circ} 42^{\prime} \mathrm{N} ; 50^{\circ} 30^{\prime}-55^{\circ} 36^{\prime}\right.$ E) occupies an area of about 133,299 $\mathrm{km}^{2}$ and covers $8.1 \%$ of Iranian territory (Nafarzadegan et al., 2012). Mean annual precipitation in the region is approximately $335 \mathrm{~mm}$, with estimated actual evaporation of $220 \mathrm{~mm}$ and recharge of $65 \mathrm{~mm}$ (Tavanpour and Ghaemi, 2016). Daily precipitation data for the present study, recorded at Sarvestan, the closest meteorological station to the study area were obtained from Fars regional water authority.

Fars province is an important agricultural region in Iran, producing cereal, citrus fruits, dates, sugar beet and cotton. About $94 \%$ of water consumption is in the agriculture sector, which dramatically adds to the water crisis in the region. Moreover, low irrigation efficiency, which has been estimated to be near $30 \%$, intensifies utilization of water resources in Fars.

Low efficiency is due to lack of fundamental irrigation facilities, poor skill and education of farmers and poor governance of water resources in Iran. For instance, the average depletion of the GW level on the Arsanjan, Khir, Estahban and Niriz plains is estimated to be 12, 8, 9 and $6 \mathrm{~m}$ during the past 16, 11, 11 and 13 years, respectively (Hojati and Boustani, 2010).

More than 500 MAR systems have been built (or are planned) on river tributaries in Fars province to increase GW storage (Subgroup, 2004). One of these, Kamal Abad MAR (Figure 1), was used as the case in this study. It is located in Sarvestan County (28 50'24.42" N, 52 28'45.10"E) and has the capability for storing roughly $680,000 \mathrm{~m}^{3}$. It was constructed on an ephemeral river on one of the sub-basins of Lake Maharlou, also known as Daryache-ye-Namak (which means salt lake), a shallow lake with maximum $220 \mathrm{~km}^{2}$ surface area located south-east of Shiraz city in central Fars province. The sub-basin is $31 \mathrm{~km}^{2}$ which is mainly covered with gramineous vegetation and shrubs. The length of the river is $13 \mathrm{~km}$. The Kamal Abad MAR system is $3.60 \mathrm{~km}$ upstream from the confluence of the ephemeral river with the main river. The main soil type is fluvial stream bed armored with rock and coarse gravel, with hydraulic conductivity of $5.10^{-4} \mathrm{~m} \cdot \mathrm{s}^{-1}$ based on the field measurements. The fluvial stream bed thickness varies from 50 to $200 \mathrm{~m}$ (Torabi Haghighi et al., 2007).

Technically, Kamal Abad MAR comprises an embankment or earth dam with a horizontal drain (filter) in the downstream toe to control recharge and piping in body of structure. The embankment is $10 \mathrm{~m}$ in height at its highest point has a 1200-m length of crest. The water discharges to downstream through an outlet pipe (diameter $40 \mathrm{~cm}$ ) located at the bottom of the structure, at $0.70 \mathrm{~m}$ above the embankment bed. An anti-seep collar is installed around the pipe as erosion protection. The step spillway is positioned $7 \mathrm{~m}$ from the bed of the MAR, to prevent flow over topping the earth dam (Torabi Haghighi et al., 2007). 

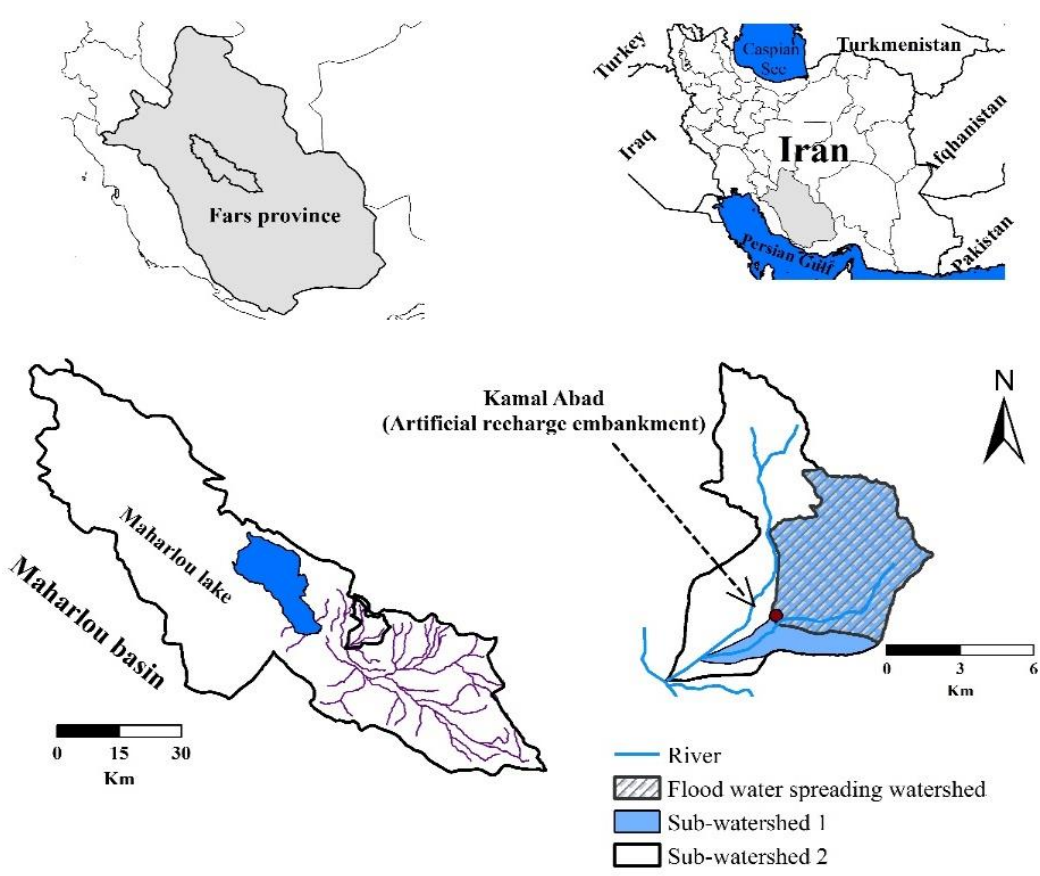

Figure 1: Maps showing the location of the study area in Lake Maharlou basin, Fars province, Iran, the Kamal Abad sub-basin and its managed aquifer recharge (MAR) embankment and the stream network.

102 The water volume for different elevations over the area affected by MAR was calculated using height and area data Figure $2 \mathrm{~b}$ obtained from a topographical map Figure $2 \mathrm{a}$. The volume of the reservoir is $260,000 \mathrm{~m}^{3}$ and the area influenced is $86,000 \mathrm{~m}^{2}$ when the water level is 7 meters. The water volume reaches $680,000 \mathrm{~m}^{3}$ is regard to maximum water level $(10 \mathrm{~m})$ in reservoir during designing flood 106 spillway.

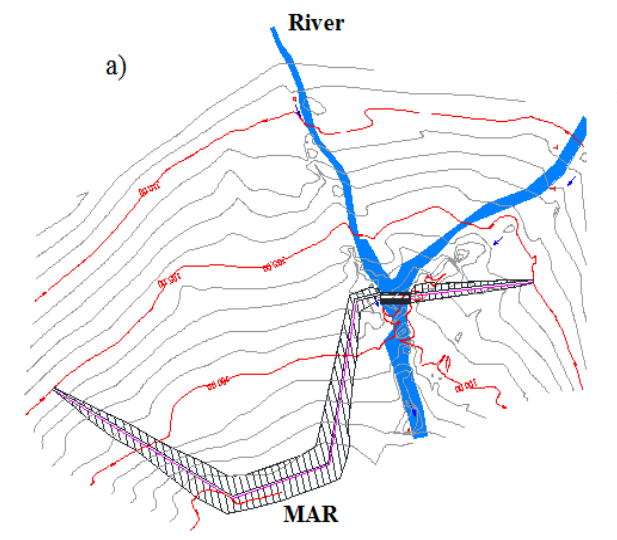

b)
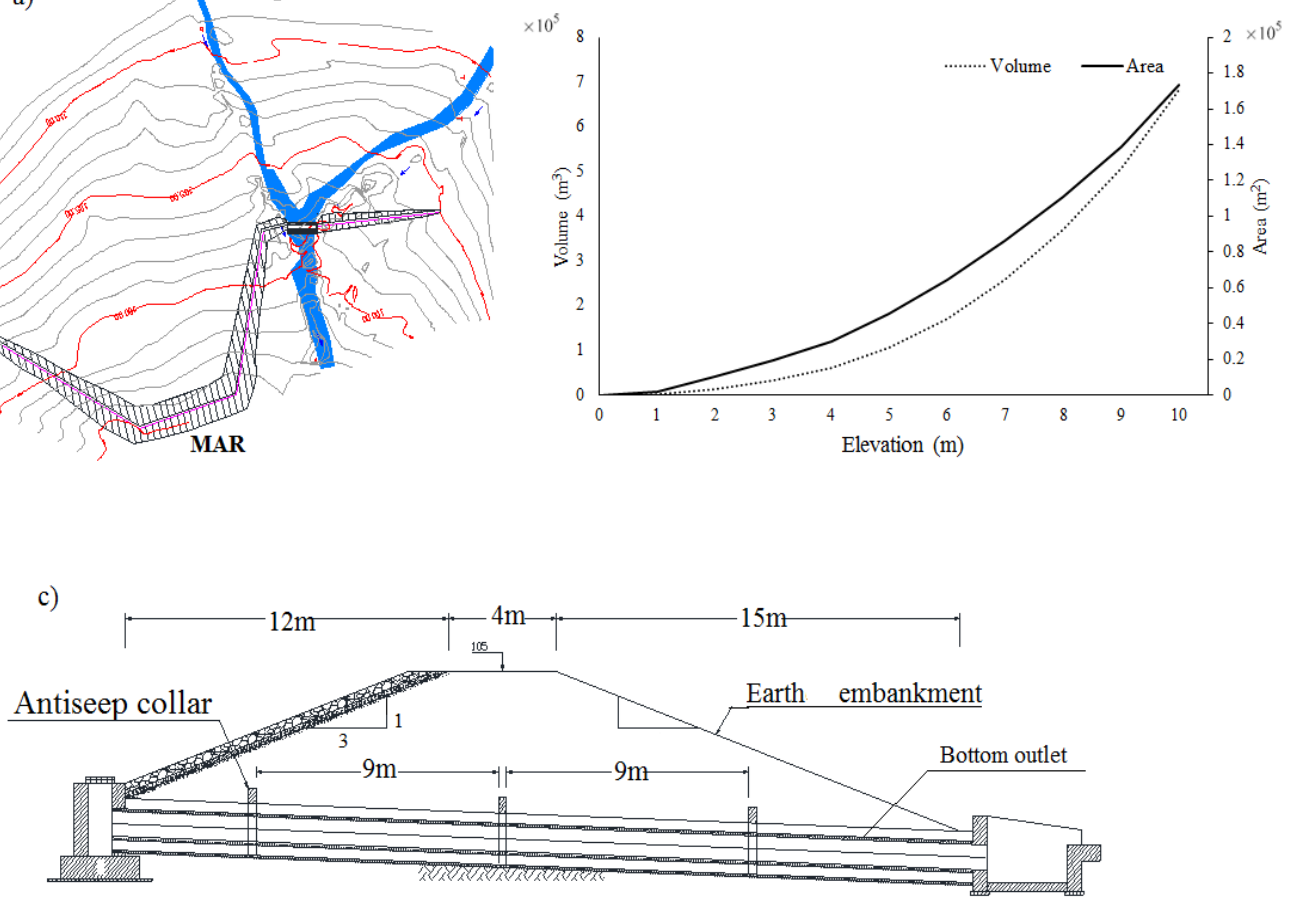

Figure 2: Technical information on Kamal Abad managed aquifer recharge (MAR) facility. a) Layout and topography, b) hypsometric curve of the reservoir (area-volume-elevation) and c) cross-section and bottom outlet. 


\subsection{Methodology}

The framework we developed is based on rainfall-runoff modeling, reservoir and river flood routing and recharge analysis. First, the runoff to the Kamal Abad MAR system was estimated. This was considered to be the inflow to the river that Kamal Abad MAR has been constructed on. This was considered as inflow that is not altered by any structure as a first scenario called "without MAR". Then recharged and delay in the basin were calculated. The outflow from the MAR is called the second scenario (with MAR). Recharge occurs in the MAR basin and in the river upstream and downstream of the structure.

As the structure was constructed on an ephemeral river without any gauging station, maximum daily precipitation was used to assess rainfall return periods of 5, 10, 20, 50 and 100 years. Corresponding precipitation was estimated to be $21,25,32,36$ and $40 \mathrm{~mm}$ respectively. A rainfall intensity-durationfrequency (IDF) curve was developed (Figure 3a) based on the calculated maximum daily data using experimental Eq. 1 and 2 for the region derived by Ghahreman and Abkhezr (2004). They used long term rainfall data (1972-2004) to adopt the method to be valid also for estimating 10-year hourly rainfall.

$P_{60}^{10}=1.34 \times P_{24}^{0.694}$

$P_{T}^{t}=(0.4524+0.247 \ln (T-0.6000))\left(0.3710+0.618 t^{0.4484}\right) P_{10}^{60}$

where: $P_{60}^{10}=$ one-hour precipitation with a 10 -year return period $(\mathrm{mm})$,

$\mathrm{T}=$ duration of precipitation $(\mathrm{h})$

$\mathrm{t}=$ return period (years)

$\mathrm{P}_{24}=$ daily average precipitation $(\mathrm{mm})$.
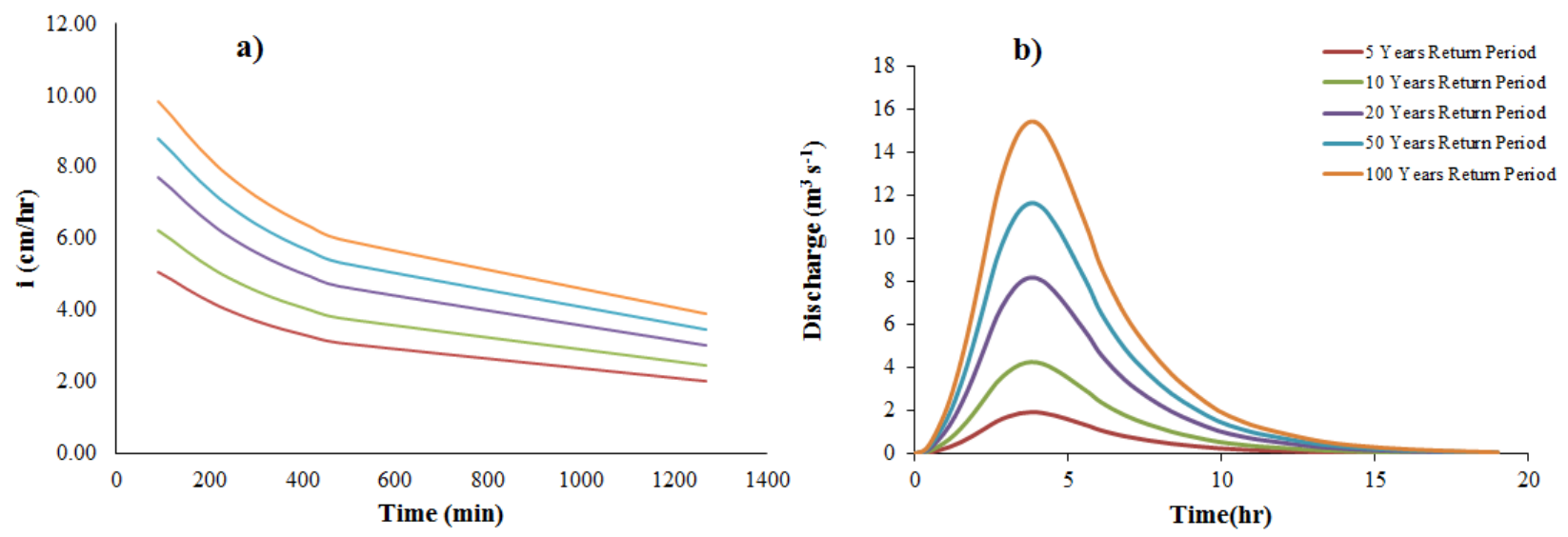

Figure 3: Rainfall and runoff for five different return periods in the study area: a) Rainfall intensity-duration-frequency and b) Hydrograph of the scenario "without MAR" derived by the USA Soil Conservation Service-Curve Number (SCS-CN) method.

In the absence of flow rate data for the study area, inflows were calculated using hydrographs with different return periods, by applying the synthetic unit hydrograph curve number $(\mathrm{CN})$ method provided by the United States Soil Conservation Service (SCS) through rainfall-runoff modeling (Figure 3). In the SCS-CN method, curve number has a considerable influence on the inflow 
hydrograph and needs to be selected carefully (Ajmal et al., 2015). The case study catchment comprises poorly consolidated alluvial-pluvial deposits on young terraces consisting of sub-rounded gravels and sand, silt and clay (Torabi Haghighi et al., 2007). Based on the exported information, the soil was set in the group A, which means that it has low runoff potential, high infiltration rate and a high rate of water transmission. For this group, the $\mathrm{CN}$ value is assumed to be 81 . Another factor which is essential in synthetic unit hydrograph curve number $(\mathrm{CN})$ method is time of concentration. Time of concentration is a conceptual value which is generally used to measure the basin's response to the precipitation event. It can be known as a time that water needs to flow from the most remote point in a basin to the outlet. Thus, it depends on the topography, geology and land use of the basin (Chow et al., 1987). Time of concentration in our case study was 3.46 hours.

The outflow from the MAR structure (Figure 4) was calculated based on flood routing (Eq. 3-7) and primary recharge (Eq. 8-9). Assessment of flood routing of the reservoir was based on the Level Pool methodology defined by (Chow et al., 1987). The outlet diameter of the structure, the area-volume curve (Figure $2 b$ ) and reservoir conditions were considered the main characteristics in flood routing. Moreover, recharge water to the aquifer $(\mathrm{q}(\mathrm{t})$ ) was deducted from the outlet water amount to define the total outflow from the structure, and thus bed soil material had a marked impact on the outflow. Compared with the inflow, the outflow showed lower peak discharge and longer runoff duration (Figure 4).

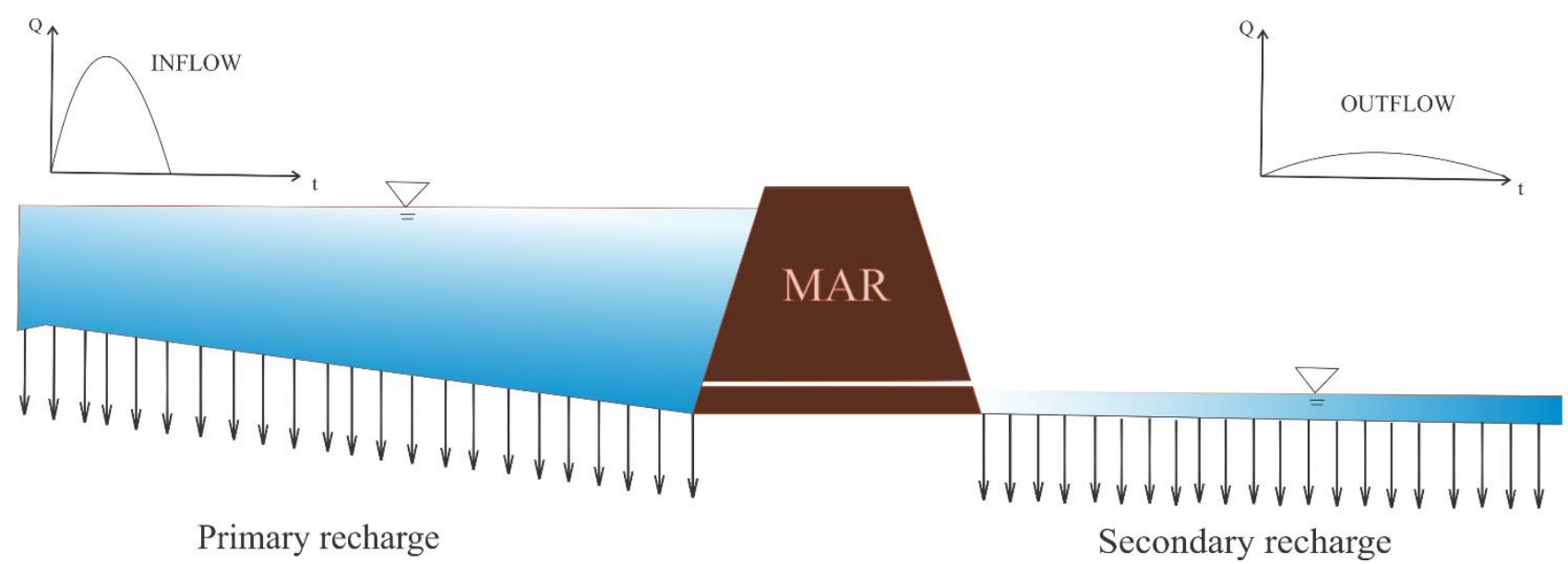

Figure 4: Schematic diagram showing the functioning of Kamal Abad Managed Aquifer recharge (MAR) structure.

$$
\begin{aligned}
& Q=C *\left(\frac{\pi d^{2}}{4}\right) *(2 * g * h)^{0.5} \\
& \frac{d S}{d t}=I(t)-Q(t)-q(t) \\
& \int_{S j}^{S j+1} d S=\int_{j \Delta t}^{(j+1) \Delta t} I d t-\int_{j \Delta t}^{(j+1) \Delta t} Q d t-\int_{j \Delta t}^{(j+1) \Delta t} q d t
\end{aligned}
$$$$
\frac{S j+1-S j}{\Delta t}=\frac{I j+1+I j}{2}-\frac{Q j+1+Q j}{2}-\frac{q j+1+q j}{2}
$$$$
\frac{2 S j+1}{\Delta t}+Q j+1=I(j+1)+I j+\frac{2 S j}{\Delta t}-Q-q
$$ 
$\mathrm{q}=$ recharge water to the aquifer $\left(\mathrm{m}^{3} \mathrm{~s}^{-1}\right)$

$175 \mathrm{~h}=$ water elevation in reservoir $(\mathrm{m})$,

$176 \mathrm{I}=$ inflow $\left(\mathrm{m}^{3} \mathrm{~s}^{-1}\right)$,

$177 \mathrm{Q}=$ outflow $\left(\mathrm{m}^{3} \mathrm{~s}^{-1}\right)$,

$178 \mathrm{~S}=$ storage $\left(\mathrm{m}^{3}\right)$,

$179 \mathrm{t}=$ time $(\mathrm{s})$,

$180 \mathrm{j}=$ interval factor.

181 Two type of flow changes were assumed to occur when MAR is applied, here defined as primary and 182 secondary recharge. Primary recharge occurs through reservoir recharge from the pond of the MAR 183 (which is considered the main recharge process). Secondary recharge occurs in the river downstream 184 of the MAR structure Figure 4.

185 The GEO-Studio SEEP (2007) was used to model the primary recharge pathways and estimate the magnitude of recharge water, which was assumed to be a function of water level in the reservoir. SEEP/W is formulated on the basis that the flow of water through both saturated and unsaturated soil follows Darcy's Law which states that (GEO-SLOPE International Ltd., 2013):

$$
q=K * i
$$

190 Where:

$191 \mathrm{q}=$ specific discharge $\left(\mathrm{m} \mathrm{s}^{-1}\right)$,

$\mathrm{K}=$ hydraulic conductivity $\left(\mathrm{m} \mathrm{s}^{-1}\right)$,

$193 \mathrm{i}=$ gradient of total hydraulic head

194 Therefore, the general governing differential equation for two-dimensional steady state seepage can 195 be expressed as:

$$
K_{x}\left(\frac{\partial^{2} H}{\partial x^{2}}\right)+K_{y}\left(\frac{\partial^{2} H}{\partial y^{2}}\right)+Q=0
$$

197 Where:

$198 \mathrm{~K}_{\mathrm{x}}=$ hydraulic conductivity in the $\mathrm{x}$-direction $\left(\mathrm{m} \mathrm{s}^{-1}\right)$

$199 \mathrm{~K}_{\mathrm{y}}=$ hydraulic conductivity in the $\mathrm{y}$-direction $\left(\mathrm{m} \mathrm{s}^{-1}\right)$

$200 \quad \mathrm{H}=$ total head $(\mathrm{m})$

$201 \mathrm{Q}=$ applied boundary flux $\left(\mathrm{m} \mathrm{s}^{-1}\right)$

For the GEO-Studio SEEP model, the seepage through the dam was calculated by setting the boundary condition (BC) at water level in the pond and at atmospheric pressure outside the pond (after the MAR structure). The BC in the infiltration basin behind the MAR structure is a function of water level in the reservoir $(\mathrm{H})$, which varies between 0 and $10 \mathrm{~m}$. It was assumed that the water entering the MAR earth dam also recharges the aquifer. Infiltration through the pond was calculated for a $1-\mathrm{m}$ section and multiplied by the wet area to obtain the total water flux for different $\mathrm{H}(0-10 \mathrm{~m})$. By considering different upstream boundary conditions (different values of $\mathrm{H}$ in Eq. 9), the relationship between recharged flow and water elevation in the reservoir was estimated and 
represented as the primary recharge rating curve (Figure 5a). Due to the shape of reservoir, the wet area increase with depth which effect the shape of the primary recharge rating curve (Figure 5 a).

The secondary recharge was also determined using the GEO-Studio/SEEP model (2007). Secondary recharge is a function of water level in river (can be varied spatially and temporally) and hydraulic conductivity of the river bed. Potential recharge face BC was selected for river edges (wetted perimeter), indicating that no additional stream water was added to or taken from the river. As the river flows only during large rainfall events, we assume no groundwater inflows to the river and the river is considered a "loosing river". Also, the river has no inflows from tributaries after the MAR structure, so there is no need to consider inflows to the river system. The seepage through the river was estimated for different water levels in the river (0-2 m). Different values of seepage flow for $1 \mathrm{~m}$ length of the river was derived from the GEO-Studio/SEEP model and represented as recharge rating curve of the river (Figure $5 \mathrm{~b}$ ). Due to a small increase of wet area by increasing water level, the curve obtained is linear.
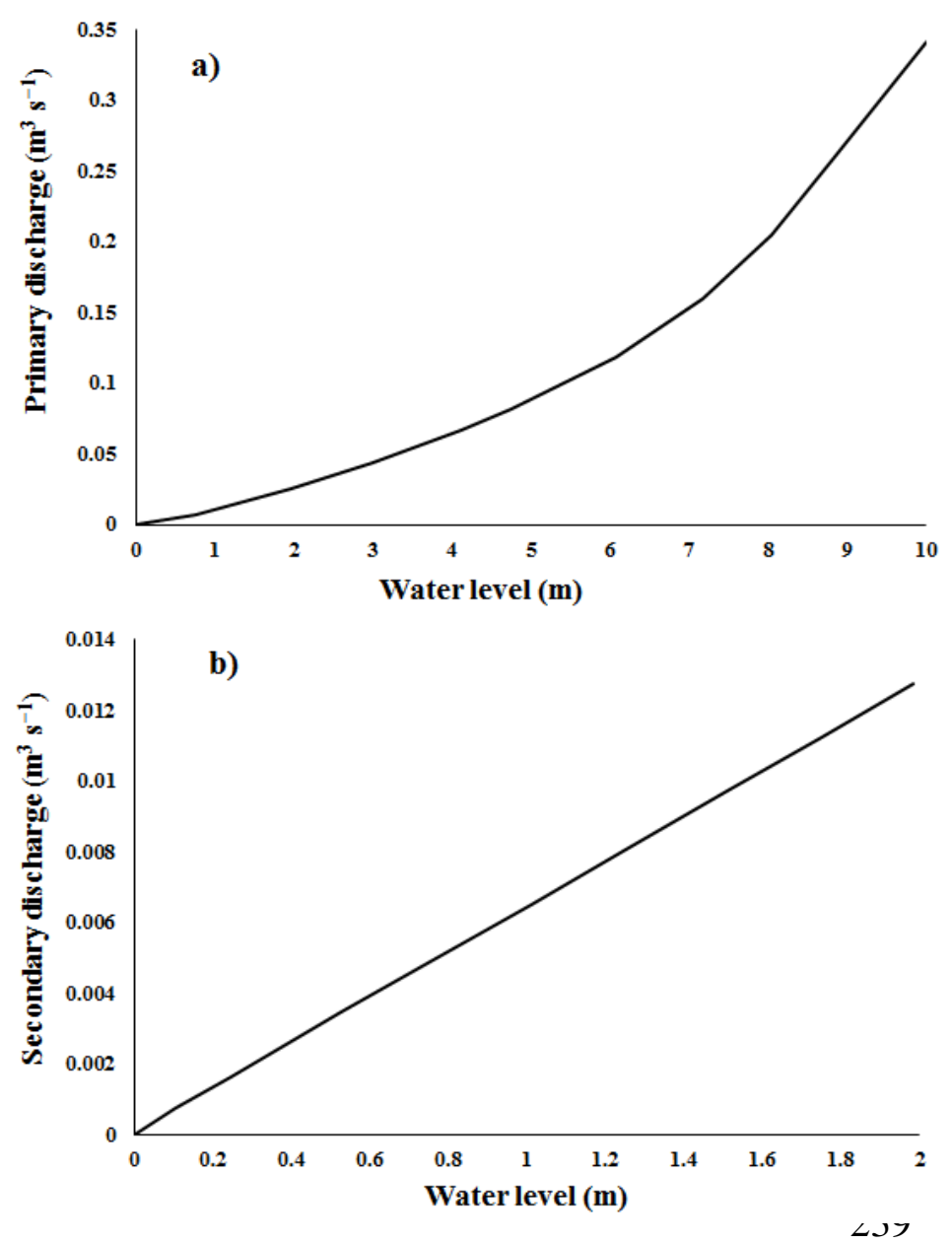

Figure 5: Recharge rating curve for a) the Kamal Abad managed aquifer recharge (MAR) reservoir (primary recharge) and b) along the 1-m river length assumed for exfiltration (secondary recharge). 
HEC-RAS (Version 5.0.3) was used to obtain the value of water level in the river for different flowrates 0 to $20 \mathrm{~m}^{3} \mathrm{~s}^{-1}$ (Figure 6). Totally 10 cross sections of the river (mean width of $60 \mathrm{~m}$ and the maximum water depth of $2 \mathrm{~m}$ ) was set after the MAR structure for $3600 \mathrm{~m}$ river length. According to field investigations (Torabi Haghighi et al., 2007) and classification of the river bed material, the selected Manning number for the river is 0.038 .

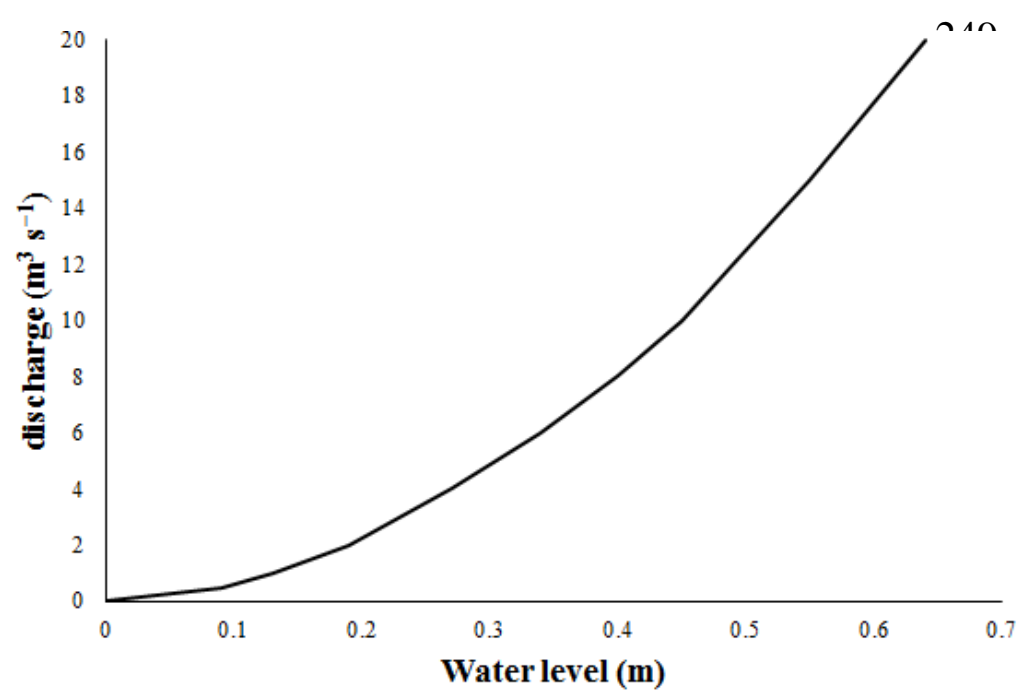

Figure 6: River rating curve (river discharge as a function of water table) derived using HEC-RAS River Analysis System.

To estimate the river flow alteration after the MAR structure and determine the length of the river before the river flow disappeared, the following multi-stage framework was developed (Figure 7).

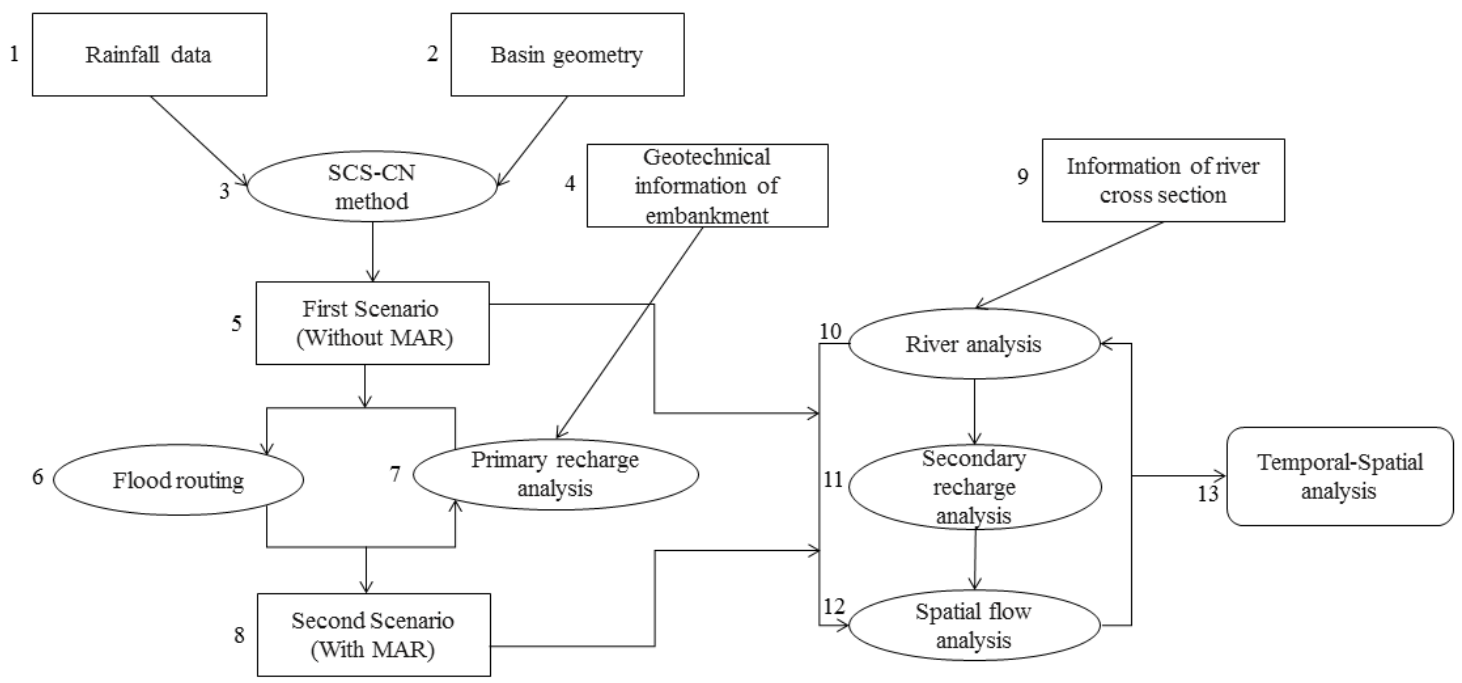

Figure 7: Multi-stage framework flow chart for managed aquifer recharge (MAR) applications.

There are several input in the framework. First hydrographs with different return periods (the inflow in the river) is determined by SCS-CN method (item 3 in the Figure 7) where basin geometry and rainfall data are needed to estimate the flow in the river in the scenario Without MAR (item 5). After this, primary recharge magnitude is calculated as shown in Figure 6a. The river flow is also the input for the flood routing (item 6) and primary recharge analysis (item7) functions, which run simultaneously to produce outflow from the MAR which is the scenario named with MAR (item 8). Both scenarios are basic requirements for the further analysis (river Analysis, secondary recharge 
analysis and spatial flow analysis) which are run simultaneously. The main part of the procedure, 278 which clarifies the distance of river before the river water disappeared after the structure, is 279 represented by these three modeling stages (items 10-12) and the result of the framework is obtained 280 at item 13 which gives us the distance that river disappears at.

281 The distance between structure outlet and the point at which the river connect to the next stream is considered as the main river section influenced by MAR. The river is divided into $10-\mathrm{cm}$ longitudinal elements to calculate the outflow from each element after secondary recharge application. The calculation starts at the first element, for which inflow is the outflow from the bottom outlet, and then the outflow of the first element is the inflow for the next one. Based on the magnitude of flow and rating curve of the river, the water level in the current element of the river can be estimated. Based on the water level in this element and rating curve of secondary recharge, the magnitude of recharge along the specific element is estimated. The recharge flow is subtracted from river flow serving as inflow for the next element. The interaction between the secondary recharge rating curve and river rating curve is the main key for solving our conceptual model.

291 The calculation of river flow is continued until the difference between inflow and outflow of each element reaches $1.10^{-3} \mathrm{~m}^{3} \mathrm{~s}^{-1}$. The flow routing to the next element is continued until all flow seeps along the river (river disappears) or the river joins the downstream river. Through this multi-stage framework, the flow, water level and recharge flow at different points in different times can be specified. The calculation is carried out for both scenarios, to discover the response of the river system along the river. Comparisons between scenarios can reveal the impact of MAR on flow conditions in the downstream river. Technically, the framework is developed in MATLAB using input data derived from SCS-CN method and HEC-RAS \& GEO-STUDIO/SEEP 2007 software. 
a)

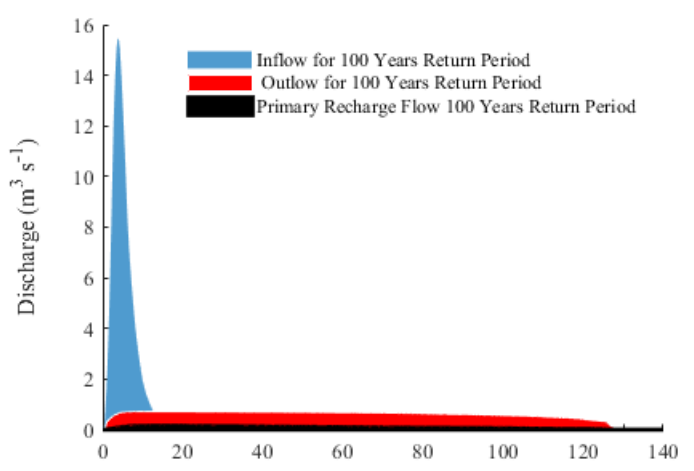

c)

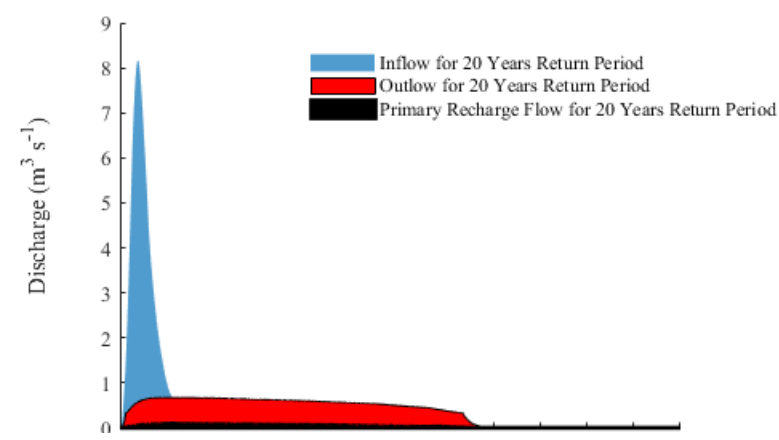

b)

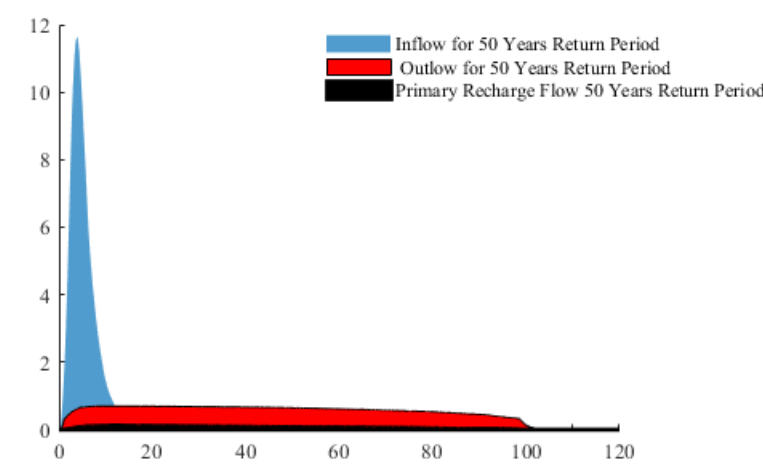

d)

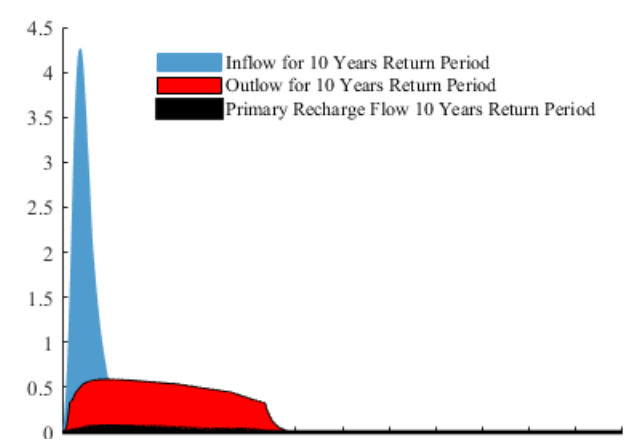

Figure 8: Inflow, outflow and primary recharge flow rate for Kamal Abad managed aquifer recharge during a) 100-year, b) 50-year, -c) 20-year and d) 10-year return periods.

\subsection{MAR and increased $\mathrm{GW}$ recharge}

The MAR structure increased primary and secondary recharge in the river. The secondary recharge increased as the flow duration increased in the river section connected to the aquifer. The primary recharge volume to the aquifer at the central cross-section of the MAR during flood routing was 6644, 18977, 41964, 65972 and $95388 \mathrm{~m}^{3}$ for a 5, 10, 20, 50 and 100 years return period, respectively (Figure 9).

The secondary recharge for "with MAR" scenario varied between 29,000 and $190,000 \mathrm{~m}^{3}$ for different floods of 5 to 100 years return periods (Figure 9). The amount of secondary recharge was significantly more than primary recharge due to longer runoff duration and bigger area for seepage potential along the river, which allow more recharge (Figure 9). The MAR increase the recharge volume by about $18-33 \%$ in the aquifer. 


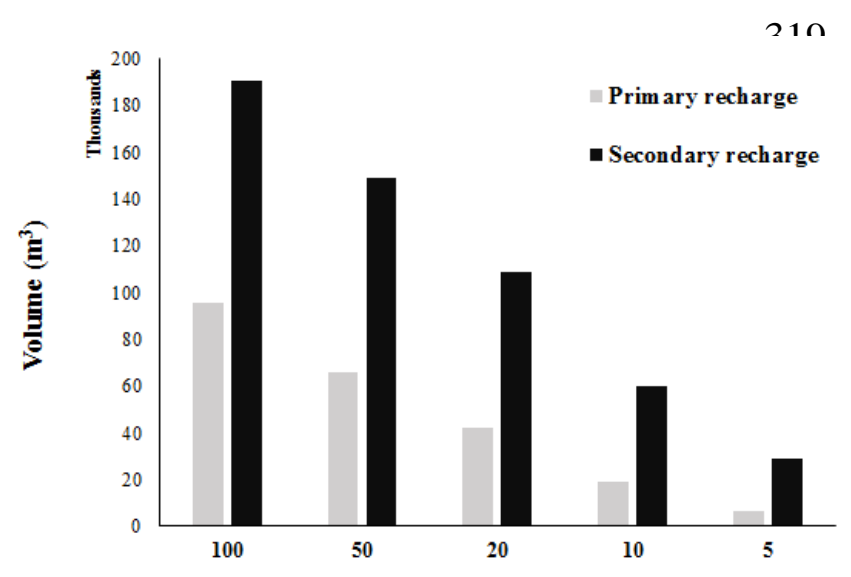

Figure 9: Comparison of primary and secondary recharge at Kamal Abad managed aquifer recharge for different return periods.

\subsection{Spatial-temporal flow alteration in river flow}

The hydrographs for both scenarios (With MAR and Without MAR) diminished along the river due to secondary recharge (Figure 10). The distance from the outlet of the MAR structure to the downstream river was approximately $3600 \mathrm{~m}$. It was calculated that "without MAR" scenario with a 100, 50, 20, 10 and 5 years return period would last for 5753, 5214, 4604, 3796 and $3036 \mathrm{~m}$ of river length, which means that only floods with a 10 years return period or more can meet the downstream river as seen in Figures 10 and 11.

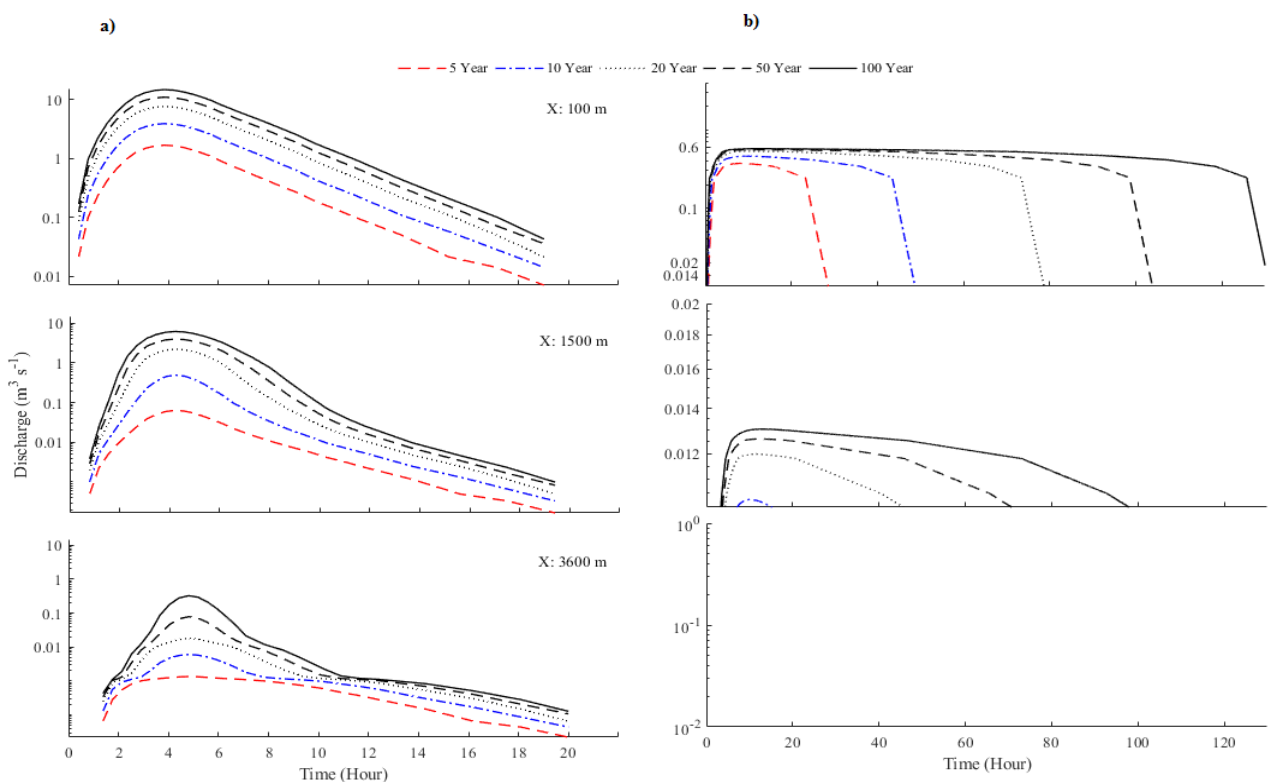

Figure 10: Spatial flow analysis along the river for the a) without MAR scenario and b) with MAR scenario for Kamal

At the downstream of MAR, the river disappeared at a maximum of $1500 \mathrm{~m}$ distance from the MAR structure. This represented a significant change, as before construction of Kamal Abad MAR floods with a 10 year return period or higher contributed to downstream discharge. In Figure 11, a decline in discharge of scenarios for different return periods along the river channel can be seen. Due to MAR, the flow with maximum peak discharge of $0.2 \mathrm{~m}^{3} \mathrm{~s}^{-1}$ occurs at $500 \mathrm{~m}$ distance from the outlet 
pipe, whereas before construction of MAR this discharge happens after $4000 \mathrm{~m}$. Without MAR construction and the primary recharge to the aquifer, the flow could join to the downstream river. The results show if the MAR was constructed in $1 \mathrm{~km}$ further downstream, water reaches the river downstream even with primary recharge (Figure 11).
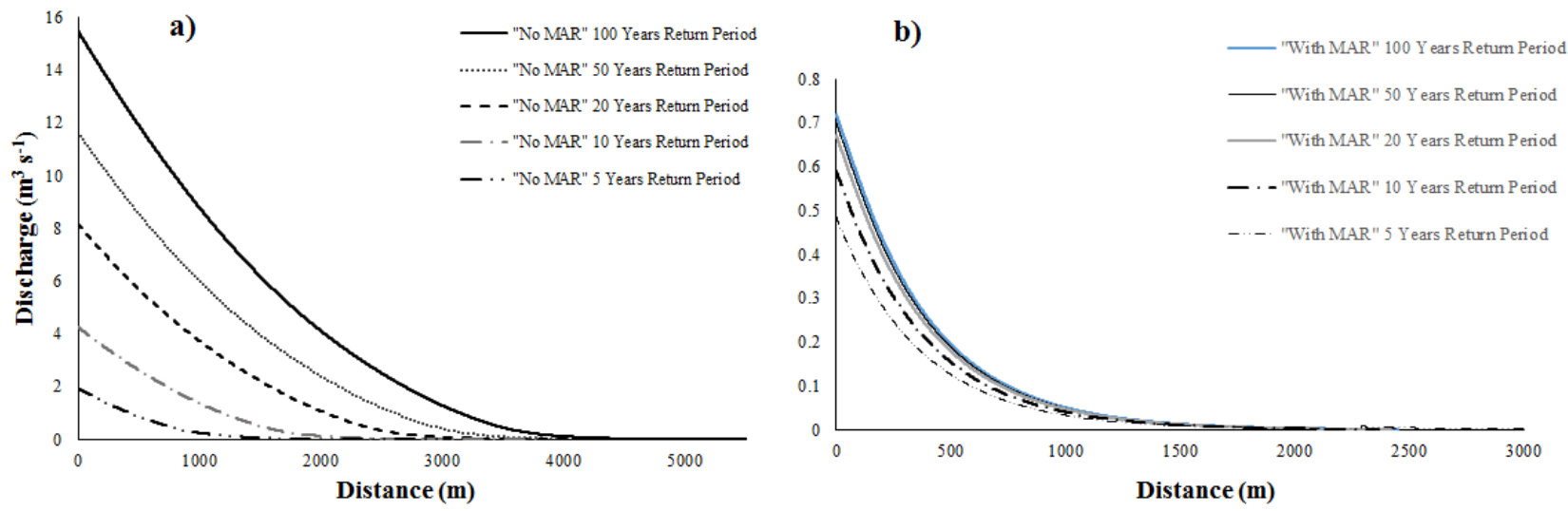

Figure 11: Decline in maximum discharge with increasing distance from the Kamal Abad MAR for two scenarios a) "wWithout MAR b) wW-ith MAR.

\section{Discussion}

A benefit of MAR structures is to increase recharge to allow for stable and increased groundwater supply (Dillon, 2005). This has allowed agriculture to develop in semiarid regions providing many socio-economic benefits. However, the impacts of MAR at catchment scale or on river flows has not been much studied.

Increased irrigation in arid regions, such as Iran, has significantly reduced river flow to downstream water systems (Fazel et al., 2017). This means that ephemeral rivers such as the study case dry up more often. To solve this, even more MAR structures have been constructed in the Lake Maharlou watershed, which can be predict to accelerate the observed decline in water levels in the region. Based on the results of this study, the existing MAR structure seems to be over-designed, as the storage capacity of Kamal Abad MAR is about 680,000 m3, while the volume of the flood with a 100 -year return period is only about $285,000 \mathrm{~m}^{3}$. The framework presented here is the first systematic approach to study the impacts of MAR on river regimes. However, there are some uncertainties, for example lack of information on (i) field conditions, (ii) the rainfall-runoff modeling component, (iii) soil properties, (iv) recharge and (v) river analysis components.

Hydraulic conductivity and river morphology would most certainly have an influence on primary (before MAR) and secondary (After MAR) recharge. Generally the hydraulic conductivity of the soil is seen the most important characteristic to control recharge (Wösten et al., 2013). Also in our framework, recharge analysis, particularly from the river bed, plays a major role in revealing the effects of MAR on river flow. To model recharge flow in this study, hydraulic conductivity of soil was based on a few field samples taken from the reservoir and the river bed materials (Torabi Haghighi et al., 2007). Despite of the lack of the data, the determined soil hydraulic conductivity values used agrees with the range of soil properties in the available standard. For instance, under Swiss Standard SN 670 010b, which has been used in previous studies (Gashti et al., 2014; Yiediboe et al., 2015), the river bed soil has been classified to be well graded gravel and sandy gravel with little 
or no fines (similar to observed conditions in Kamal Abad) and the hydraulic conductivity of the soil could vary between 0.0005 and $0.05 \mathrm{~m} \mathrm{~s}^{-1}$. For Kamal Abad, we considered value of $0.00075 \mathrm{~ms}^{-1}$ for river bed and embankment.

Although the river water level fluctuated in both the primary and secondary recharge analysis, to simplify the process in the framework the recharge rating curve was developed under a quasi-steadystate conditions by simulation of recharge for variable water levels. This simplification is justified to analyze the overall effects of MAR would not have a large effect on the recharge or flow. A full transient simulation would require more time and resources and this steady-state assumption is the first step for understanding the MAR impacts on the flow regime of the river. Also sedimentation effect on seepage flows and evaporation losses in the reservoir was not considered which is counted as future.

\section{Conclusion}

Managed Aquifer Recharge (MAR) is a promising method to increase groundwater recharge and reduce floods in arid and semi-arid regions. However, MAR has the potential to change river flows significantly, an issue that has not been studied sufficiently in the past. In this study, we developed a framework for quantifying the impact of MAR on river flows, based on different flood return periods. The results showed that MAR increased primary recharge $18-33 \%$ as it has been supposed to do but also increase the secondary recharge from the downstream river to the GW. Increasing secondary recharge reduces the flow in the ephemeral river which reduces its connection to the main tributary, which might be important to consider in some cases. As MAR influences river flow, careful planning is required when using MAR as a method to restore GW systems and increase crop irrigation.

\section{References}

Ajmal, M., Moon, G. woo, Ahn, J. hyun, Kim, T. woong, 2015. Investigation of SCS-CN and its inspired modified models for runoff estimation in South Korean watersheds. Journal of HydroEnvironment Research 9, 592-603. doi:10.1016/j.jher.2014.11.003

Ashraf, F. Bin, Torabi Haghighi, A., Marttila, H., Kløve, B., 2016. Assessing impacts of climate change and river regulation on flow regimes in cold climate : A study of a pristine and a regulated river in the sub-arctic setting of Northern Europe. Journal of Hydrology 542, 410-422. doi:10.1016/j.jhydrol.2016.09.016

Askar, M.K., 2013. Rainfall-runoff model using the SCS-CN method and geographic information systems: A case study of Gomal River watershed. WIT Transactions on Ecology and the Environment 178, 159-170. doi:10.2495/WS130141

Beven, K.J., 2012. Rainfall-runoff modelling: the primer, Rainfall-Runoff Modelling: The Primer: Second Edition. doi:10.1002/9781119951001

Choudhary, M., Chahar, B.R., 2007. Recharge/seepage from an array of rectangular channels. Journal of Hydrology 343, 71-79. doi:10.1016/j.jhydrol.2007.06.009

Chow, V. Te, Maidment, D.R., Mays, L.W., 1987. Applied Hydrology.

Dillon, P., 2005. Future management of aquifer recharge 313-316. doi:10.1007/s10040-004-0413-6

Dillon, P., Stuyfzand, P., Grischek, T., Lluria, M., Pyne, R.D.G., Jain, R.C., Bear, J., Schwarz, J., Wang, W., 2019. Sixty years of global progress in managed aquifer recharge 1-30. 
Fazel, N., Torabi Haghighi, A., Kløve, B., 2017. Analysis of land use and climate change impacts by comparing river fl ow records for headwaters and lowland reaches. Global and Planetary Change 158, 47-56. doi:10.1016/j.gloplacha.2017.09.014

Feike, T., Khor, L.Y., Mamitimin, Y., Ha, N., Li, L., Abdusalih, N., Xiao, H., Doluschitz, R., 2017. Determination of cotton farmers' irrigation water management in arid Northwestern China. Agriculture Water Management 187, 1-10.

Gashti, E.H.N., Malaska, M., Kujala, K., 2014. Structural Behaviour of Concrete Energy Piles in Thermal Loadings 8, 1248-1252.

GEO-SLOPE International Ltd., 2013. Seepage Modeling with SEEP/W 197.

Ghahreman, B., Abkhezr, H., 2004. improve the Intensity-Duration-Frequency equations in Iran. Science and Technology of Agriculture and Natural Resources.

Ghayoumian, J., Mohseni Saravi, M., Feiznia, S., Nouri, B., Malekian, A., 2007. Application of GIS techniques to determine areas most suitable for artificial groundwater recharge in a coastal aquifer in southern Iran. Journal of Asian Earth Sciences 30, 364-374. doi:10.1016/j.jseaes.2006.11.002

Hojati, M.H., Boustani, F., 2010. An Assessment of groundwater crisis in Iran Case study: Fars province. World academy of science, Engineering and Technology 4, 10-26.

Jahanshahi, R., Zare, M., 2016. Journal of African Earth Sciences Hydrochemical investigations for delineating salt-water intrusion into the coastal aquifer of Maharlou Lake , Iran. Journal of African Earth Sciences 121, 16-29. doi:10.1016/j.jafrearsci.2016.05.014

Jyrkama, M.I., Sykes, J.F., 2007. The impact of climate change on spatially varying groundwater recharge in the grand river watershed (Ontario). Journal of Hydrology 338, 237-250. doi:10.1016/j.jhydrol.2007.02.036

Mancosu, N., Snyder, R., Kyriakakis, G., Spano, D., 2015. Water Scarcity and Future Challenges for Food Production. Water 7, 975-992. doi:10.3390/w7030975

Nafarzadegan, A.R., Rezaeian Zadeh, M., Kherad, M., Ahani, H., Gharehkhani, A., Karampoor, M.A., Kousari, M.R., 2012. Drought area monitoring during the past three decades in Fars province, Iran. Quaternary International 250, 27-36.

Prathapar, S., Dhar, S., Raoa, G.T., Maheshwari, B., 2015. Performance and impacts of managed aquifer recharge interventions for agricultural water security: A framework for evaluation. Agriculture Water Management 159, 165-175.

Ronayne, M.J., Roudebush, J.A., Stednick, J.D., 2017. Analysis of managed aquifer recharge for retiming streamflow in an alluvial river. Journal of Hydrology 544, 373-382. doi:10.1016/j.jhydrol.2016.11.054

Sakakibara, K., Tsujimura, M., Song, X., Zhang, J., 2017. Spatiotemporal variation of the surface water effect on the groundwater recharge in a low-precipitation region: Application of the multitracer approach to the Taihang Mountains, North China. Journal of Hydrology 545, 132-144. doi:10.1016/j.jhydrol.2016.12.030

Subgroup, S., 2004. Proposal for artificial recharge projects in order to flood control to improve the quality and quantity of groundwater resources and reducing water crisis.

Tavanpour, N., Ghaemi, A.A., 2016. ZONING OF FARS PROVINCE IN TERMS OF RAIN-FED WINTER WHEAT CULTIVATION BASED ON PRECIPITATION AND ... trends in life 
sciences.

461 Torabi Haghighi, A., Habibi, H., Dianatpour, A., Mprtazavi, R., 2007. Feasibility report of KamalAbad Artificial GroundWater Recharge Structure.

Torabi Haghighi, A., Kløve, B., 2015. Limnologica A sensitivity analysis of lake water level response to changes in climate and river regimes. Limnologica 51, 118-130. doi:10.1016/j.limno.2015.02.001

Torabi Haghighi, A., Kløve, B., 2013. Development of a general river regime index ( RRI ) for intraannual flow variation based on the unit river concept and flow variation end-points. Journal of Hydrology 503, 169-177. doi:10.1016/j.jhydrol.2013.08.041

UN-Water, 2016. Water and jobs. UnitedNations World Water Assessement Programme, UNESCO,Paris,France.

Wösten, J.H.M., Verzandvoort, S.J.E., Leenaars, J.G.B., Hoogland, T., Wesseling, J.G., 2013. Soil hydraulic information for river basin studies in semi-arid regions. Geoderma 195-196, 79-86. doi:10.1016/j.geoderma.2012.11.021

Yiediboe, B., Lin, H.E., Jian, Y., Cong, L., Zhenliang, W., 2015. The Relationship between the Physical Properties of Soil and Shape Factors of its Fragmented Aggregates: A TwoDimensional Digital Image Processing and Analysis Approach 3, 1-15.

Zaidi, F.K., Nazzal, Y., Ahmed, I., Naeem, M., Jafri, M.K., 2015. Identification of potential artificial groundwater recharge zones in Northwestern Saudi Arabia using GIS and Boolean logic. Journal of African Earth Sciences 111, 156-169. doi:10.1016/j.jafrearsci.2015.07.008 